\title{
Effect of different dosages of zinc on the growth and biomass in five marine microalgae
}

\author{
Dinesh Kumar S., P. Santhanam*, S. Ananth, A. Shenbaga Devi, R. Nandakumar, \\ B. Balaji Prasath, S. Jeyanthi, T. Jayalakshmi and P. Ananthi \\ Marine Planktonology and Aquaculture Laboratory, Department of Marine Science, School of Marine Sciences, \\ Bharathidasan University, Tiruchirappalli-620 024, Tamil Nadu, India.
}

Accepted 10 December, 2013

\begin{abstract}
Marine environment often restrain toxic heavy metals that may enter into the food web via uptake by microalgae and eventually cause severe poisoning problems at higher tropic levels. The effects of Zinc cations upon growth of five native microalgal species, Chlorella marina, Isochrysis galbana, Tetraselmis sp., Nannochloropsis sp., and Dunaliella salina were evaluated. Growth inhibition of the microalgal cells were determined by exposing them to different concentrations of aqueous solutions of zinc metal for 15 days. A major reduction in cell density was observed in all the five cultures in the concentration of $50 \mathrm{ppm}$. Among the five micro algal species tested, Tetraselmis sp. alone showed growth up to $250 \mathrm{ppm}$ concentration of zinc metal till the final day $\left(15^{\text {th }}\right.$ day) of experiment.
\end{abstract}

Key words: Zinc, microalgae, heavy metal, Chlorella marina, Tetraselmis sp.

\section{INTRODUCTION}

Marine unicellular algae with towering metabolism rates fill the essential function in the primary production and focus of heavy metals, which are pollutants with multiple ingestion pathways to marine ecosystems. The hazard of heavy metal pollution is owing to its capability to move within marine and near-shore ecosystems for alonglasting length of time. By accumulating heavy metals in their cells, algae encourage further accumulation in the successive parts of the food chain, as well as in commercial aquatic organisms (Amiard et al., 1980). The responses to the occurrence of lethal concentrations of heavy metals vary considerably in different species. Among the marine organisms, phytoplankton resistant to heavy metals have been recommended as bioindicators for the assessment of marine pollution (Rijstenbeil et al., 1994; Kapkov and Belenikina, 2003, 2007). Based on the physical and chemical properties of phytoplankton, in addition to its reaction patterns, a chain of lethal heavy metals for phytoplankton has been proposed, in which the following chemical elements are arranged in the following order: $\mathrm{Hg}>\mathrm{Cu}>\mathrm{Cd}>\mathrm{Zn}>\mathrm{Pb}$ (Eichenberger, 1993). Most of the artificial methods are currently famous for removing heavy metals from aqueous solutions such as precipitation, electrolysis, ionic exchange, filtration, evaporation and others. But the main disadvantages of these methods are high cost, low efficiency, especially during removing small amounts of heavy metals and a necessity of slag committal. In order to overcome these disadvantages an alternative other than the chemical is needed for detoxication and removal of metals from aqueous solutions (Nalimova et al., 2005). Microalgae have been found to be very effective in removing heavy metals from wastewater due to their large surface area and high binding affinity (Chong et al., 2000). The toxicity 
Table 1. Summary of protocol for marine microalgae species growth inhibition bioassay.

\begin{tabular}{cll}
\hline $\mathbf{S} / \mathbf{N}$ & Task & Condition \\
\hline 1 & Test type & Static \\
2 & Temperature & $23 \pm 2^{\circ} \mathrm{C}$ \\
3 & Light quality & Cool white fluorescent lighting \\
4 & Light intensity & 5000 lux \\
5 & Illumination & $12: 12 \mathrm{~h} \mathrm{light} \mathrm{and} \mathrm{dark} \mathrm{cycle}$ \\
6 & Conical flask size & $250 \mathrm{ml}$ \\
7 & Culture solution volume & $100 \mathrm{ml}$ \\
8 & Renewal of test solutions & None \\
9 & Age of test organisms & Every 3 days \\
10 & Initial cell density in conical flasks & $1.5 \times 10^{4}$ cells $\mathrm{ml}^{-1}$ \\
11 & Number of replicate & 3 \\
12 & Mixing rate & Constant aeration \\
13 & Test medium & Walne medium \\
14 & Metal concentrations & Minimum of six and a control \\
15 & Test duration & 15 days \\
16 & Test endpoint & Growth rate \\
\hline
\end{tabular}

of heavy metals to different algal types varies (Fitzgerald and Faust, 1963). Some algal species demonstrated tolerance to different heavy metals possessing mechanisms to prevent their toxic effects on metabolism or damage of intracellular structures. Still now, most of the researchers studied the effect of heavy metal toxicity on fresh water algae cultivated under laboratory conditions. In this respect, study on the effects of the most dangerous metal zinc on the growth of algal species as an essential factor of natural phytocenoses seems enormously main, as it plays a determining role in nearshoremarine ecosystems. Identifying algae of different taxonomic ranks that are sensitive and resistant to heavy metals would also be needed for the development of biological markers of pollution in marine ecosystems. The aim of this study is to assess the effects of Zinc ${ }^{2+}$ toxicity on growth, chlorophyll production and viability of the marine microalgae such as Chlorella marina, Isochrysis galbana, Tetraselmis sp., Nannochloropsis sp. and Dunaliella salina.

\section{MATERIALS AND METHODS}

\section{Algal stock cultures}

Experiments were performed with the algal cultures such as $C$. marina, I. galbana, Tetraselmis sp., Nannochloropsis sp., and $D$. salina. These strains were obtained from the Central Institute of Brackishwater Aquaculture, Chennai. The microalgae were grown in the Walne medium at $\mathrm{pH} 8$ which was adjusted using $0.1 \mathrm{~N}$ $\mathrm{NaHCO}_{3}$ and $\mathrm{HCl}$ (Walne, 1970). Stock cultures were incubated in $250 \mathrm{ml}$ conical flasks containing $100 \mathrm{ml}$ of sterilized seawater under a photon irradiance of approximately 5000 lux (using two cool white fluorescent tube lights) in $12: 12 \mathrm{~h}$ light and dark cycle and temperature were maintained at $23 \pm 2^{\circ} \mathrm{C}$.

\section{Toxicity analysis}

Growth inhibition bioassay (Table 1) for microalgal species were conducted under laboratory conditions for fifteen days. To minimize the metal contamination, all laboratory wares contact with the culture medium were soaked in $1 \% \mathrm{HNO}_{3}$ for $24 \mathrm{~h}$ and rinsed with Milli-Q water. Zinc solution at a stock concentration of $1000 \mathrm{mg} / \mathrm{L}^{-1}$ was prepared using analytical grade $\mathrm{ZnCl}_{2} \cdot 2 \mathrm{H}_{2} \mathrm{O}$ (Dinesh Kumar et al., 2013). About $4.397 \mathrm{~g}$ of $\mathrm{ZnSO}_{4} 7 \mathrm{H}_{2} \mathrm{O}$ salt was dissolved in 1000 $\mathrm{ml}$ of distilled water to make stock solution. From the stock solution, $0.1 \mathrm{ml}$ was taken and dissolved in $100 \mathrm{ml}$ of distilled water to make $1 \mathrm{ppm}$ of zinc solution. The culture media with various zinc concentrations such as 5, 50, 250, 500, 1000 and 1500 ppm were prepared by diluting the stock according to Dinesh Kumar et al. (2013). Control medium was prepared in the same manner without adding the toxicant. A known cell density of the algal suspension with exponential growth phase was harvested from the stock cultures and inoculated in the test medium prepared with different concentrations of zinc and control fed with Walne culture medium, the initial cell density was approximately $1.5 \times 10^{4}$ cells $\mathrm{ml}^{-1}$. The growth rates of algal cultures were monitored carefully at regular intervals such as 3, 6, 9, 12 and 15 days of incubation by measuring the optical density of algal suspension at $650 \mathrm{~nm}$ (Wetherell, 1961). Triplicates were maintained for all the treatments and control.

At the end of experiment chlorophyll 'a' content of the microalgal cultures was estimated by following the method of Mantoura and Llewellyn (1983). As brief $10 \mathrm{ml}$ of algal culture sample was filtered using Millipore filtering system fitted with a $4.5 \mathrm{~cm}$ diameter GF/C filter paper by applying low suction. Before filtering the sample, a thin bed of magnesium carbonate $(2 \mathrm{ml})$ was poured over the GF/C filter paper for effective filtration. After filtration, the filtrate was removed and filter paper with algal cells ground with $90 \%$ of acetone using mortar and pestle. The resulting samples were transferred to screw cap test tubes covered with black cloth and incubated in the refrigerator for $24 \mathrm{~h}$. After $24 \mathrm{~h}$ incubation, the contents were ground with $90 \%$ of acetone and centrifuged at 3000 rpm for $10 \mathrm{~min}$. Then the clear supernatant was collected and optical density was measured at different wavelengths such as 630 , 645 and $665 \mathrm{~nm}$ using UV- visible Spectrophotometer (1800 


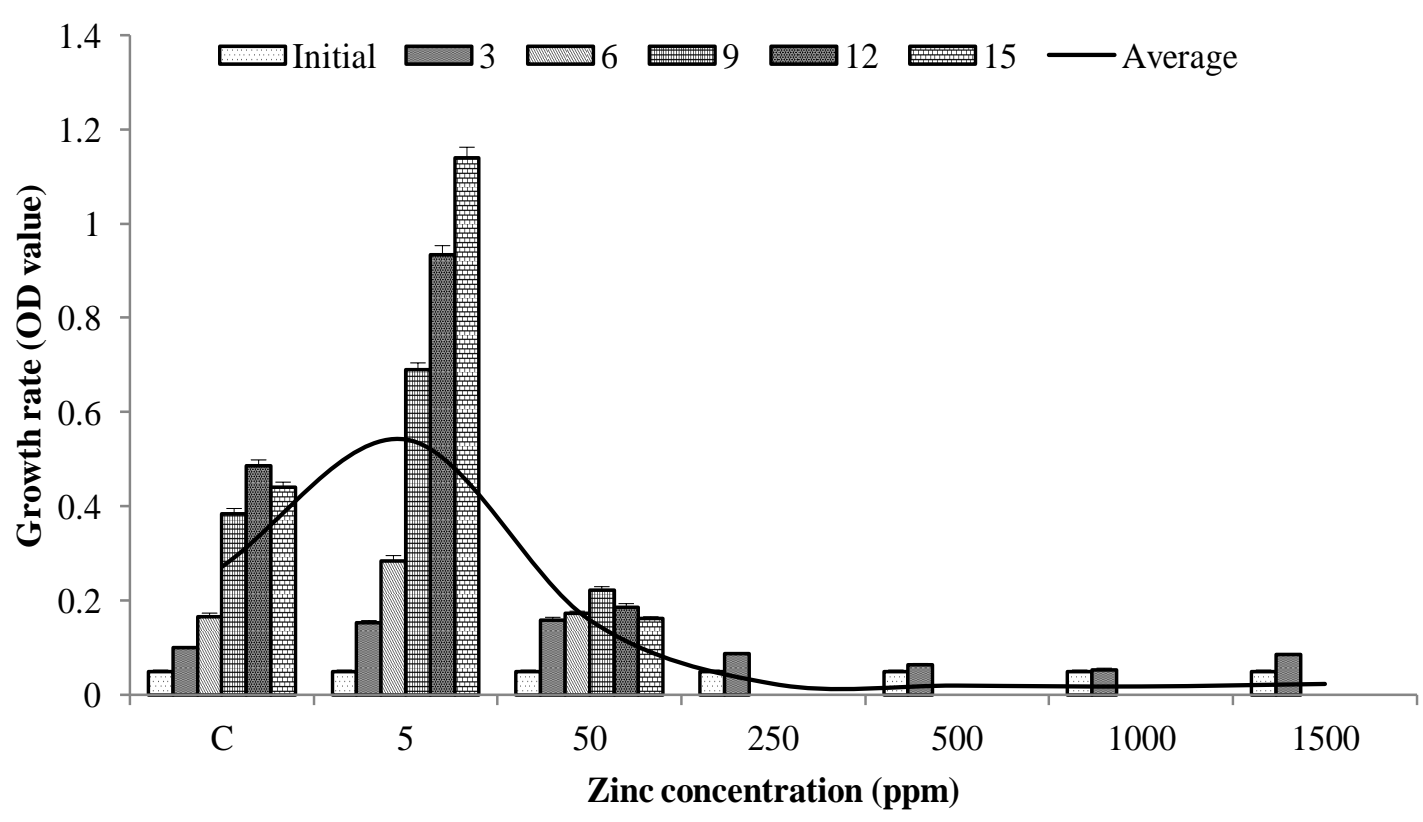

Figure 1. Effect of zinc on the growth of $C$. marina.

Shimadzu UV) for chlorophyll 'a' estimation.

\section{RESULTS AND DISCUSSION}

\section{Effect of zinc on the growth of the microalgal cultures}

In the present investigation, the effect of zinc on the growth of unicellular marine microalgae such as $C$. marina, I. galbana, Tetraselmis sp., Nannochloropsis sp., and $D$. salina were evaluated by using growth inhibition bioassay. The result indicates that the Chlorella marina showed good growth (average- $0.101 \pm 0.003 \mathrm{abs}$ ) in all the concentration of zinc up to 3 days of incubation. However, when the concentration of the zinc and incubation days increased, the growth of $C$. marina decreased drastically. The Chlorella marina displayed good growth in 5 and $50 \mathrm{ppm}$ concentration of zinc compared to the control $(0.153 \pm 0.005$ and $0.158 \pm 0.007$ abs respectively). The growth rate was significantly increased in $5 \mathrm{ppm}$ of zinc concentration up to 15 days of incubation. Though, the growth rate of $C$. marina was less in $50 \mathrm{ppm}(0.158 \pm 0.005 \mathrm{abs})$ when compared to the control $(0.271 \pm 0.012 \mathrm{abs})$, it show's steady growth up to the end of the experiment (Figure 1). These results were accordance with the previous published data on other algae (Kamp-Nielsen, 1971; Nazzi, 1972; Rachlin and Farran, 1974).

The inhibitory effect of zinc on the microalgae $I$. galbana demonstrated that their growth was decreased after 3 days of incubation as C. marina. In $50 \mathrm{ppm}$ zinc concentration, the growth $(0.113 \pm 0.019$ abs $)$ was found to increase from the initial cell density $(0.05 \pm 0.002 \mathrm{abs})$ till 6 days of incubation and after that a steady growth rate was observed till the end of the experiment. The increased optical density $(0.278 \pm 0.035$ abs $)$ in $5 \mathrm{ppm}$ concentration of zinc up to 15 days of incubation showed that the I. galbana had good ability to tolerate at $5 \mathrm{ppm}$ of zinc concentration. In addition, comparatively the cell density of $I$. galbana was high during $12(0.257 \pm 0.029$ abs) and 15 days $(0.278 \pm 0.02$ abs $)$ of incubation than the control which denotes that they have grown well in the Walne medium with the presence of $5 \mathrm{ppm}$ of zinc (Figure 2). It is clear that after $9^{\text {th }}$ day the algal growth was found to be reduced with reference to metal concentration. It is understand that the metal concentration have made significant adverse impact on the algal growth as agreed earlier by Davies (1974). However, Fisher et al. (1984) have stated that the surface reactivity of the I. galbana did not showed any change for heavy metals over an incubation period. It is also suggested that the variability of metal accumulation in algae is probably the result of competition between the metals to bind with such polysaccharides (Kohn, 1975; Hurlburet et al., 1976; Veroy et al., 1980).

The optical density results of Tetraselmis sp. revealed that they were able to tolerate up to the concentration of $250 \mathrm{ppm}$ zinc whereas in the highest concentrations such as 500, 1000 and $1500 \mathrm{ppm}$ of zinc no growth was observed after 3 days of incubation. The maximum growth in Tetraselmis sp. was observed in 50 and 250 ppm concentrations as $0.498 \pm 0.049$ and $0.387 \pm 0.043$ abs respectively on $15^{\text {th }}$ day of incubation (Figure 3 ). Zinc can easily be rationalized since it is a micronutrient required for microalgal metabolism (Bascik-Remisiewicz et al., 2009; Vallee and Auld, 1990) as it is a part of 


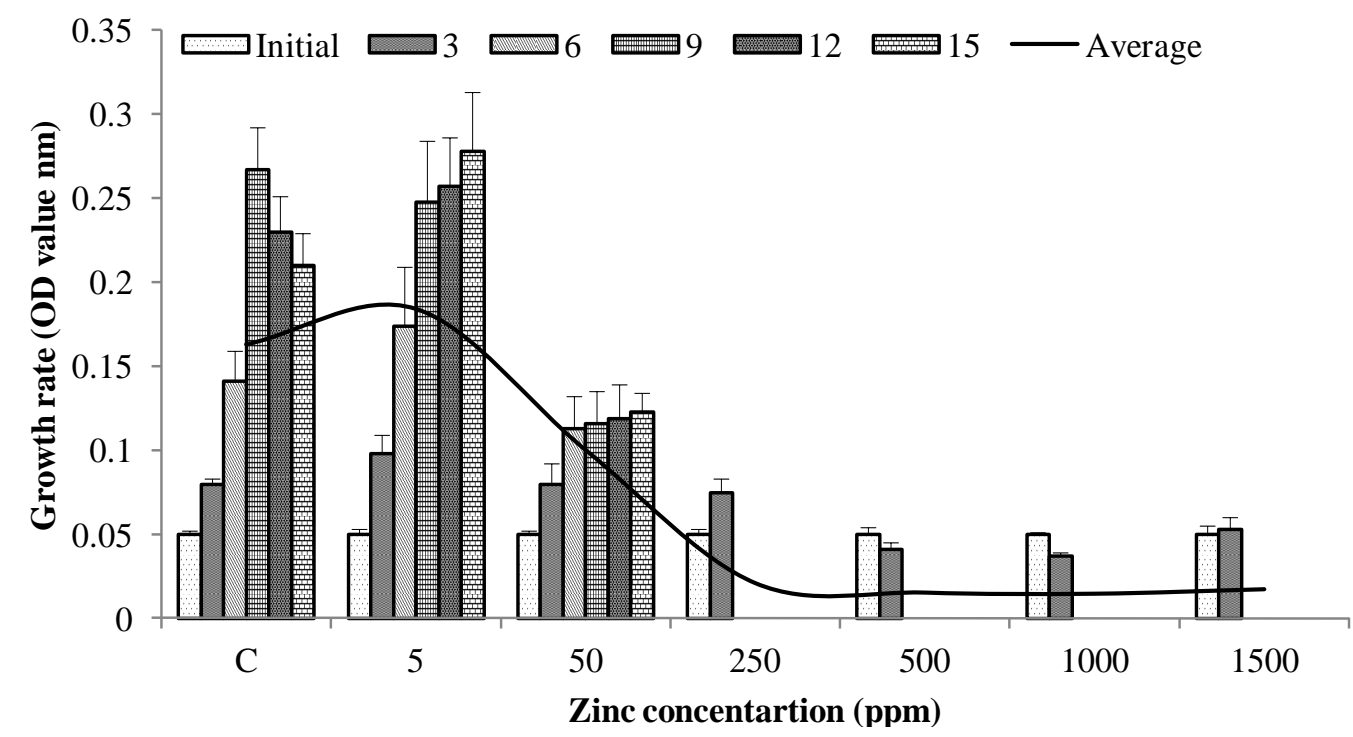

Figure 2. Effect of zinc on the growth of $I$. galbana.

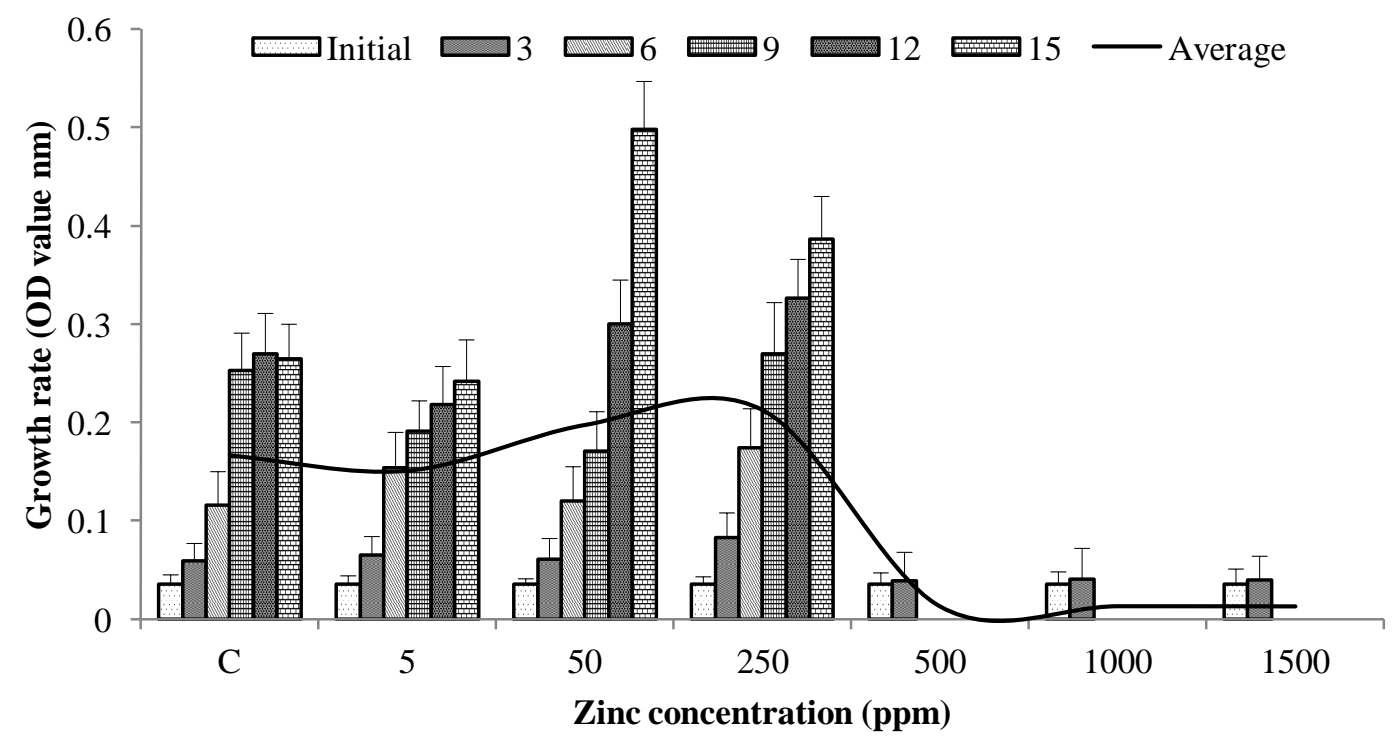

Figure 3. Effect of zinc on the growth of Tetraselmis sp.

prosthetic moieties of some of its relevant enzymes. In the present study, the toxicity effect of zinc was progressively decreased when the exposure time was increased which was judged by the increased growth rate of the cultures. This may be due to the accumulation of zinc onto algal cells in higher concentrations which significantly reduced the available zinc concentration and its toxicity to surviving cells in the final stage of experiment as agreed by Lim et al. (2006). Interestingly, the growth rate of the Tetraselmis sp., was found higher in the zinc supplemented medium than the control medium (without heavy metal) which clearly defined that the zinc act as growth stimulant of the Tetraselmis sp. and it can survive up to $250 \mathrm{ppm}$ zinc concentration.

The effect of zinc on Nannochloropsis sp. was obtained by measuring the growth at $650 \mathrm{~nm}$ which showed that, they were relatively high in $5(0.312 \pm 0.035 \mathrm{abs})$ and 50 ppm $(0.288 \pm 0.029$ abs) than the control $(0.283 \pm 0.035$ abs) up to $6^{\text {th }}$ day of incubation. At the $9^{\text {th }}$ day of incubation, the growth rate was increased in $5 \mathrm{ppm}$ and decreased at $50 \mathrm{ppm}$ zinc concentration. After $9^{\text {th }}$ day of incubation, growth rate was decreased from an initial value of $0.36 \pm 0.037$ to $0.268 \pm 0.031$ abs at $5 \mathrm{ppm}$ concentration whereas in highest concentrations such as 250, 500, 1000 and $1500 \mathrm{ppm}$, no growth was noticed after 3 days of incubation, which denotes that the culture 


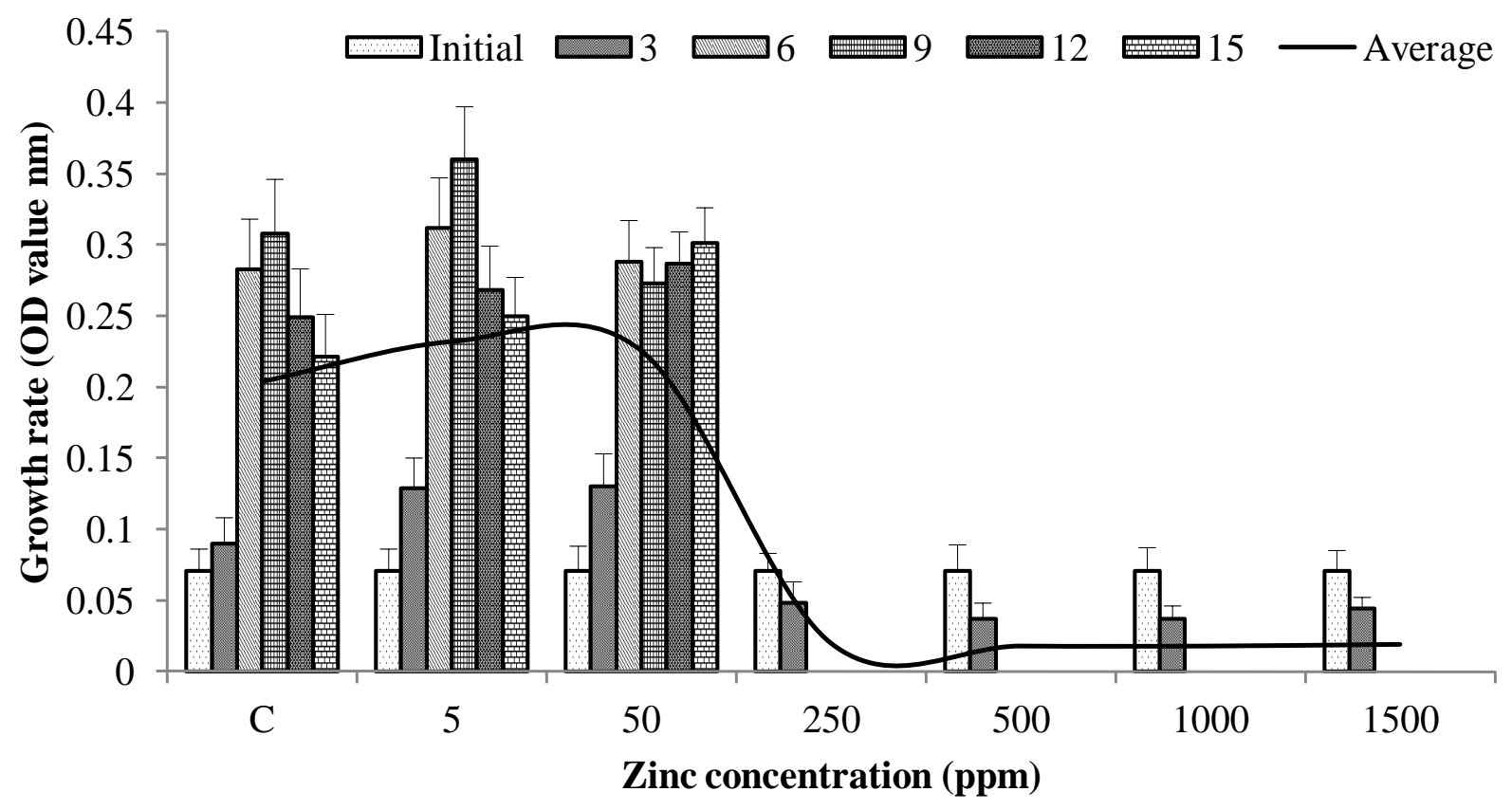

Figure 4. Effect of zinc on the growth of Nannochloropsis sp.

could not tolerate when the concentration of zinc increased (Figure 4). This occurs because the metal ion is interacted with the fat layer on the surface of microalgae cells (Darmono, 1995). The body surface of microalgae is covered by the cell membrane, therefore, the potential interaction between the membrane and the metal ion in the water is high (Fhencel, 1988). The surface of cells contains various functional groups, such as $\mathrm{N}$-terminal of $-\mathrm{NH}_{2}$, C-terminal of - $\mathrm{COO}^{-}$, S-terminal of $-\mathrm{SH}$ and functional groups of side chains which are potential as metal binding sites. Binding of the metal ion by the active groups proceeds on the cell surface followed by the slow transport step into the membrane and then to the cytoplasm (Chu and Hashim, 2007). Accumulation of several metals (such as $\mathrm{Zn}, \mathrm{Co}, \mathrm{Mo}, \mathrm{Ca}$, and $\mathrm{Mg}$ ) on algae occurs through the intracellular active biological transport. Toxic heavy metal ions can be isolated from the cytoplasm of the cell through three possible ways that is intracellular chelating by biological polymers; precipitation of heavy metals on the surface of cell wall; or surface adsorption through metal ion binding by chemical functional groups on the cell wall (MorenoGarrido et al., 1998). The present results showed that the Nanochloropsis sp., can survive up to $50 \mathrm{ppm}$ of zinc concentration as agreed by Hala et al. (2012).

In all the tested concentrations of zinc, the growth of $D$. salina was not completely inhibited. In high zinc concentration, slow growth was observed and maximum growth inhibition $(0.329 \pm 0.039$ abs) was noticed after 6 days of exposure to $50,250,500,1000$ and $1500 \mathrm{ppm}$ (Figure 5). In control, the growth was found good after 3 days of incubation and it was gradually decreased when the incubation days prolonged. When compared to control $(0.198 \pm 0.019$ abs) the growth of $D$. salina was found to be higher $(0.226 \pm 0.039$ abs $)$ at $5 \mathrm{ppm}$ of zinc concentration till the end of the experiment. The present result suggests that $D$. salina can survive up to $5 \mathrm{ppm}$ of zinc concentration could be attributed the metal binding affinity to the cell surface coat. This conclusion is in accordance with the suggestion made by Davies (1974) who stated that the cellular surface of rnicroalgae consists of a mosaic of cationic and anionic exchange sites acting as ion exchangers for anionic and cationic species in the medium. The amount of metal bound to the ce1l surface coat at equilibrium should be a function of the affinities of the binding sites for the metal, the chemical form of the metal and its concentration in the medium. So, zinc can affects the microalgal growth during the growth period as agreed by previous researchers (Rebhun and Amotz, 1986; Imani et al., 2011; Shariati and Yahyaabadi, 2006).

On an average the relative growth rates of the algae tested decreased upon increasing zinc content in the sea water. Most of the trace metals are known to promote microalgal growth at low concentrations and inhibits at high concentrations, though, the impact may vary with type of metal and the microlagal species (Gao et al., 2004). In this study the tolerance limit of zinc was $50 \mathrm{ppm}$ except Tetraselmis sp. (250 ppm) and D. salina (5 ppm). Among the microalgae tested Tetraselmis sp. alone tolerated $\mathrm{Zn}$ concentrations up to $250 \mathrm{ppm}$. Our species were more tolerant to $\mathrm{Zn}$ concentrations than others reported (Imani et al., 2011; Tripathi and Gaur, 2006).

This may be due to the fact that this metal was an 


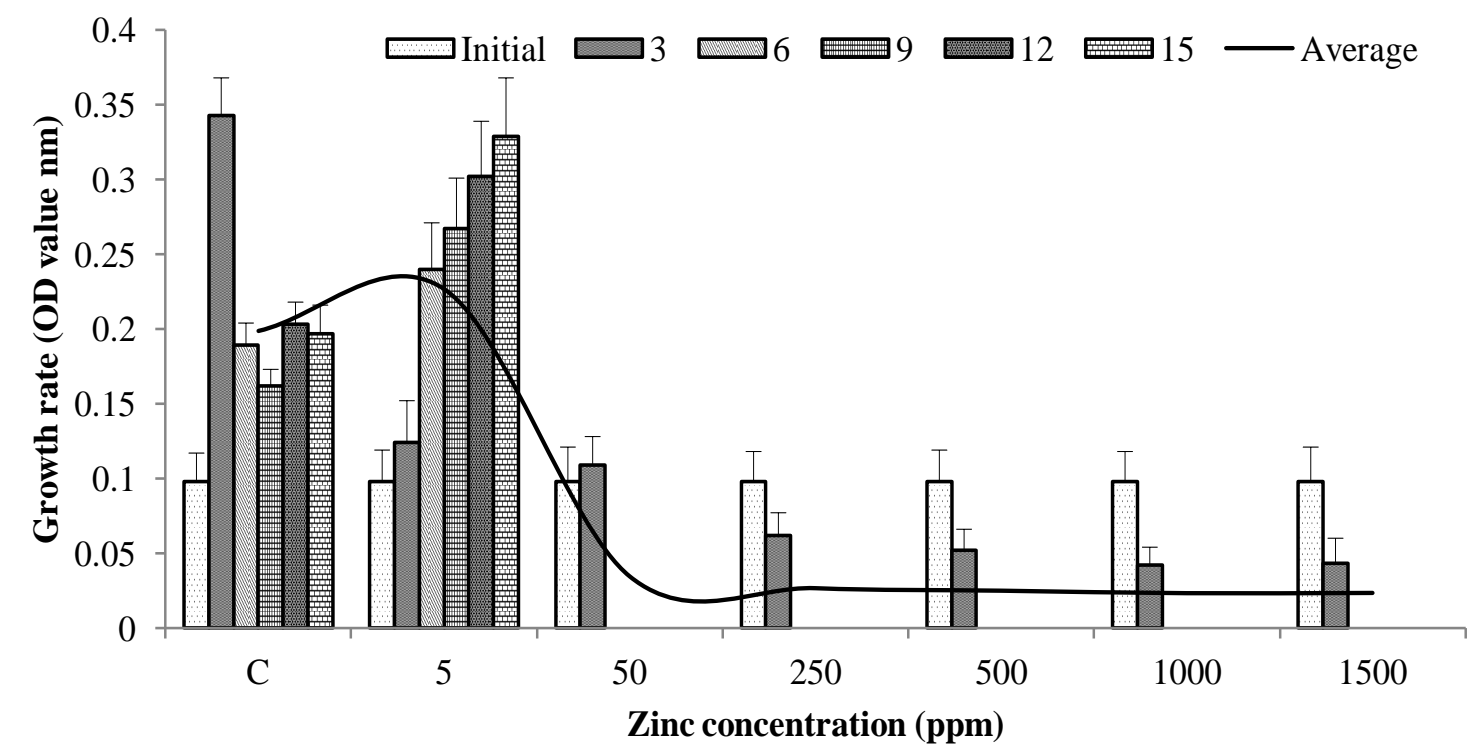

Figure 5. Effect of zinc on the growth of $D$. salina.

abundant contaminant in the original source site of our microalgae strains may account for our exceptional observations.

The effect of zinc on the algae becomes clearer when not only the growth rates in the early exponential phase, but also the total development of the cultures are considered. Many studies have proved non toxicity of zinc (in terms of cell division) at lower concentrations. Rasko and Rachin (1977) have also showed that $7.5 \mathrm{mgl}^{-1}$ $\mathrm{Zn}$ does depress the concentration of chlorophyll a, suggesting that $\mathrm{Zn}$, as well reduces algal cell division and is an aspect of its relatively mild toxicity. Thus long-term effect of the exposure to increased levels of zinc was, therefore, more serious than that expressed by the growth rate.

\section{Effect of zinc in chlorophyll 'a' concentration}

In this investigation chlorophyll ' $a$ ' content of the microalgal cultures were estimated on the final day of experiment $\left(15^{\text {th }}\right.$ day) for zinc treated cultures as well as for the control. The results declared that the zinc significantly affects the chlorophyll 'a' concentration in all the tested marine microalgal cultures. Among the five microalgae tested, the Tetraselmis sp. showed maximum chlorophyll ' $a$ ' $(8.21 \pm 0.97 \mu \mathrm{g} / \mathrm{l})$ content than rest of the algae. Likewise the lowest chlorophyll of $0.19 \pm 0.11 \mu \mathrm{g} / \mathrm{l}$ was noticed in Nannochloropsis sp. at $50 \mathrm{ppm}$. The overall average chlorophyll ' $a$ ' concentration in all the tested zinc concentration was recorded to be higher in Tetraselmis sp. $(4.81 \pm 0.52 \mu \mathrm{g} / \mathrm{l})$ followed by Isochrysis galbana $(1.80 \pm 0.14 \mu \mathrm{g} / \mathrm{l})$ and Chlorella marina $(1.11 \pm 0.22$ $\mu \mathrm{g} / \mathrm{l})$ as shown in Figure 6.

\section{Conclusion}

The present study provides clear evidence that the addition of zinc in various concentrations brings about significant differences in the growth of microalgal species due to the differences in their resistances. Our study determined the intervals between the threshold and lethal concentrations of the most dangerous heavy metals for bunch species of marine microalgae and identified the variations in resistance to this metal in various species of microalgae. From the results, we conclude that Tetraselmis sp., having the most metal tolerating ability which survives up to $250 \mathrm{ppm}$ of zinc. Except $D$. salina other microalgal species such as $C$. marina, I. galbana and Nannochloropsis sp., shows resistance up to $50 \mathrm{ppm}$ of zinc concentration. The $D$. salina can survive only 5 $\mathrm{ppm}$ zinc concentration. From the above results it could be understood that the marine phytoplankton can survive up to those limits. In view of the increasing contamination of aquatic ecosystems by toxic metals and given the placement of microalgae at the basis of the food chain, ecotoxicological studies encompassing wild strains are of greater importance towards the design of bioremediation strategies and integrated environmental monitoring.

\section{ACKNOWLEDGEMENTS}

Authors express their thanks to the Head, Department of Marine Science and authorities of Bharathidasan University for the facilities provided. Authors acknowledge Dr. A. R. Thirunavukkarasu, Principal Scientist, Fish Culture Division, Central Institute of Brackishwater Aquaculture, Chennai, for providing algal 


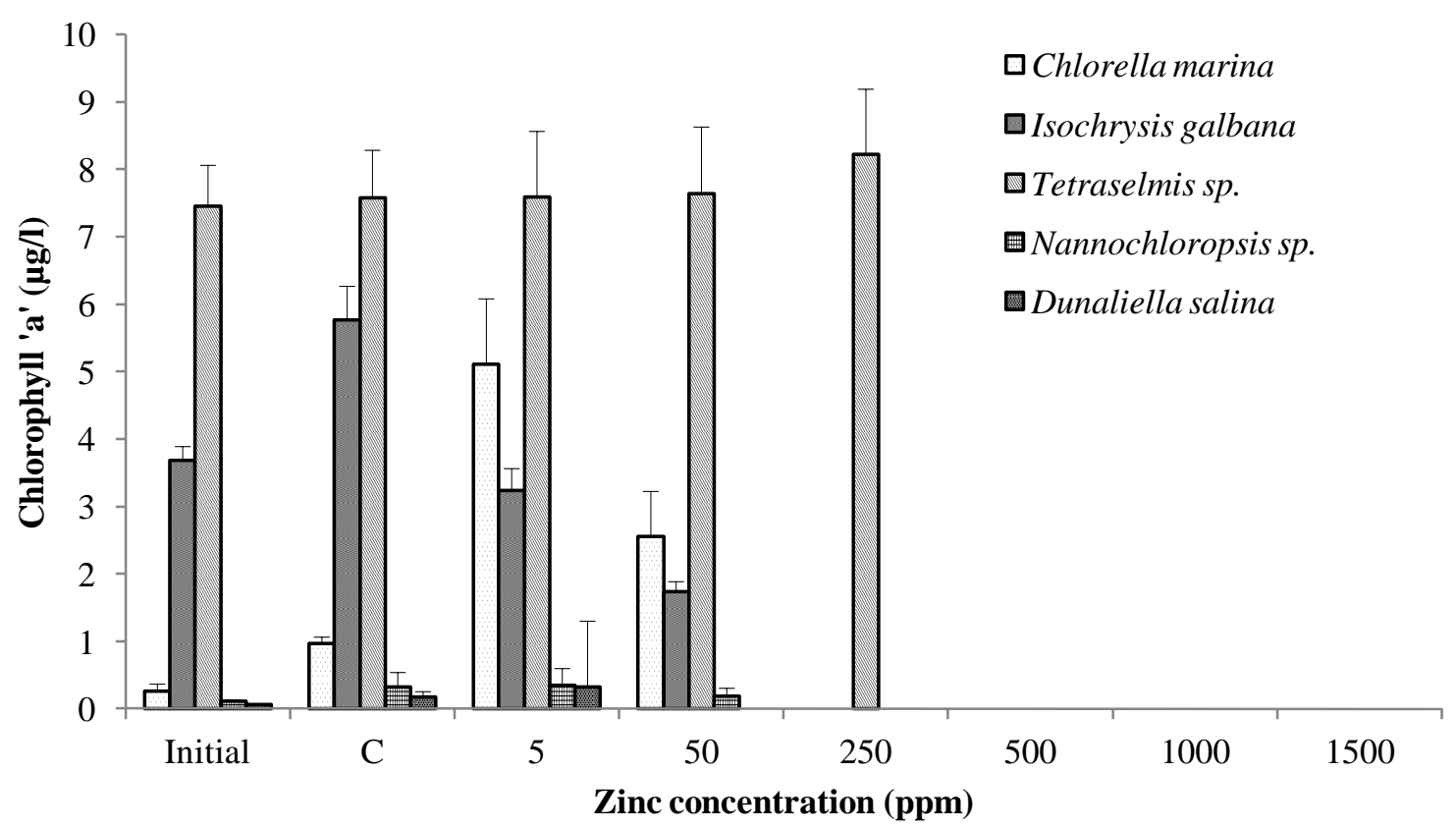

Figure 6. Effect of zinc on the chlorophyll 'a' content of five marine microalgae.

\section{culture for our experiments.}

\section{REFERENCES}

Amiard JC, Amiard-Triquet C, Metayer J, Ferre R (1980). Etude du transfert $\mathrm{DE} \mathrm{Cd}, \mathrm{Pb}, \mathrm{Cu}$ ET $\mathrm{Zn}$ dans les chaines trophiques neritiques et estuariennes-l. Etat dans l'estuaire interne de la loire (France) au cours de l'ete 1978. Water Res. 14:665-673.

Báscik-Remisiewicz A, Tomaszewska E, Labuda K, Tukaj Z (2009). The effect of $\mathrm{Zn}$ and $\mathrm{Mn}$ on the toxicity of $\mathrm{Cd}$ to the green microalga Desmodesmus armatus cultured at ambient and elevated (2\%) $\mathrm{CO}_{2}$ concentrations. Polish J. Environ. Stud. 18(5):775-780.

Chong AMY, Wong YS, Tam NFY (2000). Performance of different microalgal species in removing nickel and zinc from industrial wastewater. Chemosphere 41(1-2):251-257.

Chu KH, Hashim MA (2007). Copper biosorption on immobilized seaweed biomass: Column breakthrough characteristics. J. Environ. Sci. 19(8):928-932.

Darmono (1995). Logam dalam sistem biologi makhluk hidup, UI-Press, Penerbit Universitas Indonesia, Jakarta.

Davies AG (1974). The growth kinetics of Isochrysis galbana in cultures containing sublethal concentrations of mercuric chloride. J. Mar. Biol. Ass. U.K. 54(1):157-169.

Dinesh Kumar S, Santhanam P, Jayalakshmi T, Nandakumar R, Ananth S, Shenbaga Devi A, Balaji Prasath B (2013). Optimization of $\mathrm{pH}$ and retention time on the removal of nutrients and heavy metal (zinc) using immobilized marine microalga Chlorella marina. J. Biol. Sci. 13(5):400-405.

Eichenberger ZE (1993). Relationship between the necessity and toxicity of metals in water ecosystems. in: K.H. Zigel and A. Zigel, eds, Nekotorye voprosy toksichnosti ionov metallov (Aspects of Toxicity of Metallic lons), Moscow, Mir, pp. 62-87.

Fhencel T (1988). Marine plankton food chains. Ann. Rev. Ecol. 10(2):165-173.

Fisher NS, Bohe M, Teyssie JL (1984). Accumulation and toxicity of Cd, $\mathrm{Zn}, \mathrm{Ag}$, and $\mathrm{Hg}$ in four marine phytoplankters. Mar. Ecol. Progress Ser. 18:201-213.

Fitzgerald G, Faust SL (1963). Factors affecting the algicidal and algistatic properties of copper. Appl. Microbiol. 11(4):345-351.
Gao KS, Yan JI, Tanaka J (2004). Quantitative evaluation of wind effect during emersion on Porhpyra haitanensis(Rhodophyta), a farmed species in southern China. Fish. Sci. 70:710-712.

Hala Y, Syahrul M, Suryati E, Taba P (2012). Biosorption of $\mathrm{zn}^{2+}$ with Nannochloropsis salina. The 2nd International Seminar on New Paradigm and Innovation on Natural Sciences and its Application (INSPINSA-2), Semarang.

Hurlburet AJP, Tanaka Y, Skoryna SC (1976). Isolation and metal binding properties of fucoidan. Botanica Marina 19(5):327-328.

Imani S, Zarchi SR, Hashemi M, Borna $H$, Javid $A$, Zand AM, Abarghoue $\mathrm{HB}$ (2011). $\mathrm{Hg}, \mathrm{Cd}$ and $\mathrm{Pb}$ heavy metal bioremediation by Dunaliella alga. J. Med. Plants Res. 5(13):2775-2780.

Kamp-Nielsen L (1971). The effect of deleterious concentrations of mercury on the photosynthesis and growth of Chlorella pyrenoidosa. Physiologia Plantarum 24(3):556-561.

Kapkov VI Belenikina OA (2003). Biomarkers of pollution of marine ecosystems with heavy metals. Water Ecosyst. Organ. (Moscow), 6:68-69.

Kapkov VI, Belenikina OA (2007). A Study of the resistance of mass marine algae to heavy metals. Moscow Univ. Biol. Sci. Bull. 62(1):3033.

Kohn R (1975). Ion binding on polyuronates-alginate and pectin. Pure Appl. Chem. 42(3):371-397.

Lim CY, Yoo YH, Sidharthan M, Ma CW, Bang IC, Kim JM, Lee KS, Park NS, Shin HW (2006). Effects of copper (I) oxide on growth and biochemical compositions of two marine microalgae. J. Environ. Biol. 27(3):461-466.

Mantoura RFC, Llewellyn GA (1983). The rapid determination of algal chlorophyll and carotenoid and their breakdown products in natural waters by reverse-phase high-performance liquid chromatography. Analitica Chimica Acta 151:297-314.

Moreno-Garrido I, Blasco J, Gonzalez-Delvalle M, Lubian LM (1998). Differences in copper accumulation by the marine microalga Nannochloropsis gaditana Lubian, submitted to two different thermal treatments. Ecotoxicol. Environ. Restoration 1(1):43-47.

Nalimova AA, Popova VV, Tsoglin LN, Pronina NA (2005). The effects of copper and zinc on Spirulina platensis growth and heavy metal accumulation in its cells. Russ. J. Plant Physiol. 52(2): 229-234.

Nazzi R (1972). Toxicity of mercury to phytoplankton. Nature 237:38-40.

Rachlin JW, Farran M (1974). Growth response of the green algae 
Chlorella vulgaris to selective concentrations of zinc. Water Res. 8(8):575-577.

Rebhun S, Amotz AB (1986). Effect of $\mathrm{NaCl}$ concentration on cadmium uptake by the halophilic alga Dunaliella salina. Mar. Ecol. Progress Ser. 30:215-219.

Rijstenbeil JW, Derksen JW, Gerrinda LJ (1994). Oxidative stress induced by copper: Defence and damages in the marine planktonic diatomea grow in continuous culture with high-low zinc levels. Mar. Biol. 119:583-590.

Rasko JJ, Rachlin JW (1977). Effect of Cd, Hg, Zn and Pb on cell division, growth and chlorophyll a content of the chlorophyte, Chlorella vulgaris. Bull. Torrey Bot. Club 104:226-233.

Shariati M, Yahyaabadi S (2006). The effects of different concentrations of cadmium on the growth rate and beta-carotene synthesis in unicellular green algae Dunaliella salina. Iran. J. Sci. Technol. 30:5763.

Tripathi BN, Gaur JP (2006) Physiological behavior of Scenedesmus sp. during exposure to elevated levels of $\mathrm{Cu}$ and $\mathrm{Zn}$ and after withdrawal of metal stress. Protoplasma 229:1-9.

Vallee BL, Auld DS (1990). Zinc coordination, function and structure of zinc enzymes and other proteins. Biochem. 29:5647-5659.
Veroy RL, Montano N, de Guzman MLB, Laserna EC, Cajipe GJB (1980). Studies on the binding of heavy metals to algal polysaccharides from Philippine seaweeds. I. Carrageenan and the binding of lead and cadmium. Botanica Marina 23:59-62.

Walne PR (1970). Studies on the food value of nineteen genera of alga e to juvenile bivalves of the genera Ostrea, Crassostrea, Mercenaria and Mytilis. Fish. Investig. 26:1-62.

Wetherell DF (1961). Culture of fresh water algae in enriched natural sea water. Physoilogia Plantarum 14(1):1-6. 